\title{
Ureteroarterial fistula: imaging diagnosis and endovascular management
}

\author{
Chryshane L Fernandopulle, ${ }_{1}^{1}$ Rebecca Jeyaraj, ${ }^{2}$ Riad Alchanan, ${ }^{1}$ Dean Y Huang (i) ${ }^{1}$
}

${ }^{1}$ Department of Radiology, King's College Hospital, London, UK

${ }^{2}$ Department of Urology, King's College Hospital, London, UK

\section{Correspondence to \\ Dr Dean Y Huang;}

dean.huang@nhs.net

Accepted 20 August 2020

\section{DESCRIPTION}

A 65-year-old woman presented with haematuria and hypovolaemic shock. Her medical history includes International Federation of Gynaecology and Obstetrics (FIGO) stage IIIC2 serous endometrial carcinoma diagnosed 5 years previously, which was treated with transabdominal hysterectomy and bilateral salpingo-oophorectomy, adjuvant chemotherapy and radiotherapy. Two years after initial treatment, she was diagnosed with disease recurrence in the right ureter and new nodes in the coeliac, left para-aortic and right retrocrural regions. At that time, she underwent further chemotherapy and placement of a right ureteric stent for obstructive uropathy.

Her estimated glomerular filtration rate (GFR) was $36 \mathrm{~mL} / \mathrm{min} / 1.73 \mathrm{~m}^{2}$. Cystoscopy and ureteroscopy performed showed normal bladder, left ureteric and distal right ureteric mucosa. It was not possible to advance the ureteroscope beyond the distal right ureter. CT scan showed clots within the right renal calyces. The right kidney also showed significant renal cortical atrophy on CT scan, suggestive of a non-functioning right kidney. This was confirmed by a subsequent dimercaptosuccinic acid (DMSA) scan, which showed 5\% split function in the right kidney. The right kidney was thought to be the source of haematuria, and she proceeded to have a right nephrectomy and removal of the ureteric stent. The lower right ureter was not removed due to severe fixation.

Twelve days later, she had a further episode of massive haematuria. A repeat CT scan revealed an enhancing abnormality within the ureteric remnant, corresponding to the point of contact between the previous ureteric stent and the right common iliac artery (CIA) on the previous CT scan (figure 1). She proceeded to angiography that showed a CIA pseudoaneurysm. A $9 \times 37 \mathrm{~mm}$ stent graft (BeGraft,

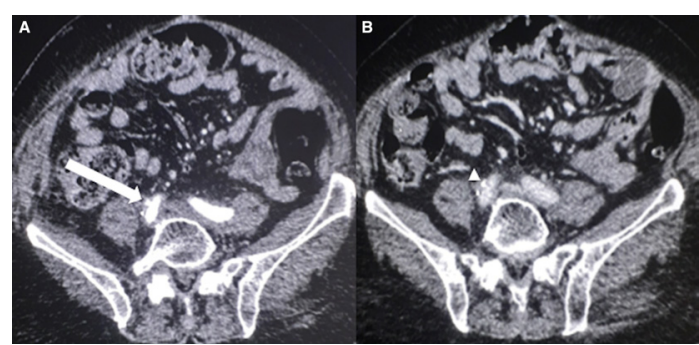

Figure 1 (A) CT angiogram that shows a small pseudoaneurysm at the ureteric stump (arrow), corresponding to the site of the point of contact between the ureteric stent (arrow head) and the right common iliac artery on the previous CT scan (B).

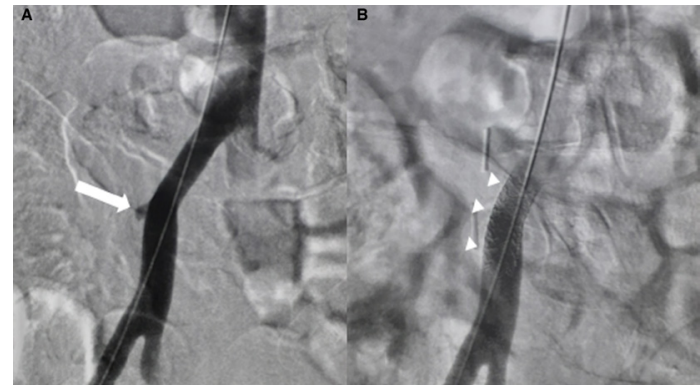

Figure 2 (A) Digital subtraction angiogram (DSA) showing a small common iliac artery pseudoaneurysm at site of ureteroarterial fistula (arrow). (B) Repeat DSA following placement of a stent graft (arrow heads) showed resolution of the pseudoaneurysm.

Bentley, Hechingen, Germany) was deployed within the CIA across the defect (figure 2). This resulted in resolution of her haematuria by postprocedure day 1. She remained asymptomatic 9 months following the procedure.

Ureteroarterial fistula (UAF) is a rare condition with only approximately 150 cases reported in the literature. ${ }^{1}$ Risk factors include chronic indwelling ureteral stents, pelvic surgery and radiotherapy and systemic chemotherapy. The diagnosis of UAF is often delayed because it is an uncommon cause of haematuria. CT scan may show an iliac artery injury near the crossing of the ureter, with ancillary findings of blood clots in the collecting system. However, the diagnostic rates with CT scan are only $42 \%-50 \% .^{2}$ Angiographic findings of UAF vary from extravasation to a subtle intimal defect. Contrast extravasation into the ureter might not occur when a ureteral stent or clots are at the site of the leak. Open surgical repair in these patients

\section{Learning points}

- Ureteroarterial fistulas (UAFs), although rare, are a possible cause of haematuria and should be considered for inpatients with predisposing risk factors.

- In cases of UAF, contrast-enhanced CT examinations may show an enhancing abnormality arising from the iliac artery near the crossing of the ureter/ureteric stent.

- Due to surgical risks and other comorbidities in patients with UAF, endovascular treatment with placement of an arterial stent graft may be the preferable management option over open surgery. 
is often difficult due to prior intervention and radiation. Endovascular management, with placement of a stent graft to exclude the fistula, reported a success rate of $85 \%-100 \% .^{34}$ Although stent-graft infection is an inherent risk, such complication after treatment of UAF has not been described to date.

In summary, it is important to consider the possibility of a UAF in patients who present with haematuria, an appropriate history and in whom other common causes of haematuria have been excluded. Endovascular treatment is a feasible and safe approach in managing a patient with UAF.

Contributors Each author (CLF, RJ, RA and DYH) made substantial contributions to the conception of the work. DYH and RA contributed to the procedures. CLF, RJ and RA contributed to the acquisition and reporting of the data. CLF, RJ and DYH contributed to the draft of the manuscript. CLF and DYH contributed to the interpretation and discussion of the case and the review of literature relating to the case.
Funding The authors have not declared a specific grant for this research from any funding agency in the public, commercial or not-for-profit sectors.

Competing interests None declared.

Patient consent for publication Obtained.

Provenance and peer review Not commissioned; externally peer reviewed.

\section{ORCID iD}

Dean Y Huang http://orcid.org/0000-0002-5637-6723

\section{REFERENCES}

1 Pillai AK, Anderson ME, Reddick MA, et al. Ureteroarterial fistula: diagnosis and management. AJR Am J Roentgenol 2015;204:W592-8.

2 van den Bergh RCN, Moll FL, de Vries J-PPM, et al. Arterioureteral fistulas: unusual suspects-systematic review of 139 cases. Urology 2009;74:251-5.

3 Fox JA, Krambeck A, McPhail EF, et al. Ureteroarterial fistula treatment with open surgery versus endovascular management: long-term outcomes. I Urol 2011:185:945-50.

4 Okada T, Yamaguchi M, Muradi A, et al. Long-Term results of endovascular stent graft placement of ureteroarterial fistula. Cardiovasc Intervent Radiol 2013;36:950-6.

Copyright 2020 BMJ Publishing Group. All rights reserved. For permission to reuse any of this content visit

https://www.bmj.com/company/products-services/rights-and-licensing/permissions/

BMJ Case Report Fellows may re-use this article for personal use and teaching without any further permission.

Become a Fellow of BMJ Case Reports today and you can:

- Submit as many cases as you like

- Enjoy fast sympathetic peer review and rapid publication of accepted articles

- Access all the published articles

Re-use any of the published material for personal use and teaching without further permission

Customer Service

If you have any further queries about your subscription, please contact our customer services team on +44 (0) 2071111105 or via email at support@bmj.com.

Visit casereports.bmj.com for more articles like this and to become a Fellow 